\title{
SEQUENTIAL ANAEROBIC AND AEROBIC TREATMENT OF PULP AND PAPER MILL EFLUENT
}

\author{
Bindhya Prem ${ }^{1}$, Vijayan $\mathrm{N}^{2}$ \\ ${ }^{1}$ M Tech scholor, Department of Environmental Engineering, College of Engineering Trivandrum, Kerala, India \\ ${ }^{2}$ Associate Professor, Department of Environmental Engineering, College of Engineering Trivandrum, Kerala, India
}

\begin{abstract}
Paper mill is one of the major sources of pollution causing industry with intensely coloured effluent. The effluent is rich in lignocellulosic materials and other chemicals used during manufacturing which results in high Bio-chemical Oxygen Demand $(B O D)$ and Chemical Oxygen Demand (COD). Due to its high toxic and mutagenic nature when discharged untreated there is a growing demand to treat the effluent before discharge. Biological treatment is a promising technique as it greatly reduces colour, $B O D$ and COD. Various fungal and bacterial species are capable of degrading the lignocellulosic materials present in the effluent.

In the present study characterization of the paper mill effluent and identification of the degradation efficiency of lignin degrading fungal species - Pleurotus species and Rhizopus stolonifer and bacterial species - Pseudomonas aeruginosa and Bacillus subtilis in laboratory scale was done. Here sequential anaerobic and aerobic treatment was carried out in two bioreactors in series.

The study indicated that anaerobic treatment gave a reduction of colour (18\%), lignin (25\%), COD (36\%), BOD (28\%) in 5 days. The anaerobically treated effluent was then separately given to the aerobic reactors containing the fungal and bacterial species. Data obtained indicated that the Rhizopus showed good reduction in colour (71\%), lignin (77\%), COD (68\%) and BOD (70\%) in 5days whereas Pleurotus, Pseudomonas and Bacillus species showed reduction in colour (68\%, 31\%, 18\%), lignin $(64 \%, 43 \%, 44 \%), \operatorname{COD}(58 \%, 42 \%, 43 \%)$ and BOD $(60 \%, 40 \%, 42 \%)$ respectively in 5 days. Thus Rhizopus was identified as the microbe with better degradation capacity.
\end{abstract}

Key Words: Pulp and paper mill effluent1, Lignin, Anaerobic treatment, Rhizopus stolonifer. $* * *$

\section{INTRODUCTION}

Pulp and paper mill is one of India's core sector industries contributing to large quantity of industrial water pollution. It utilizes a huge amount of lingo-cellulosic materials and water during the manufacturing process. Pulping processes are the major source of environmental impacts in the pulp and paper industry [9]. The wastewater is characterized by dark brown colour, extreme quantities of COD, BOD, pH, Total Dissolved Solids (TDS), Dissolved Oxygen (DO) and Suspended Solids (SS). ${ }^{[2]}$ The dark colour of the wastewater inhibits the photosynthetic activity by reducing the sunlight. As per the Ministry of Environment and Forest (MoEF), Government of India, the pulp and paper sector is in the "Red Category" list of 17 industries having a high polluting potential [3].

Various physical, chemical, biological and combinations of different methods are employed for the treatment of the pulp and paper mill effluents. Physical and chemical processes remove high molecular weight chlorinated lignins, colour, toxicants, SS and COD. But BOD and low molecular weight chloro-lignin compounds are not removed efficiently and are quite expensive [5]. Biological treatment systems which include aerated lagoons and actived sludges reduce COD and BOD, but are not efficient in reducing colour and high molecular-weight chlorolignins. The colour and the chlorinated organic compounds can be reduced by white-rot fungi, which can be used for the treatment of these effluents [6].

Microbial degradation technique has no negative impact on the environment. It is carried out by different organisms like bacteria, fungus, algae and enzymes as a single step treatment or in combination with other physical and chemical methods. The microorganism treats the effluent mainly by action of enzymes and biosorption [10]. The various enzymes involved in the treatment of pulp and paper mill effluent are lignin peroxidase, manganese peroxidase and laccase. Microorganism showing good production of these enzymes has the potency to treat effluent [4]. Different bacterial species include Bacillus subtilis, Citrobactor freundi, Alcaligenes, Burkholderia, Pseudomonas aeruginosa, etc and fungal species include Phanerochaete chrysosporium, Rhisopus stolonifer, Pleurotus eryngii, Pleurotus ostreatus, etc.

Shanthi et al., [9] identified the predominant bacteria and fungi in paper mill effluent and the degradation efficiency of individual isolates and combination of isolates to treat the effluent and effective floc formation and degradation was attained in Pseudomonas alkaligens and Enterobacter spp. combination. Hassan et al., [3] isolated Bacillus sp. from Egyptian soil and achieved maximum lignin degradation on the 
sixth day at $\mathrm{pH} 6$ was $81.4 \%$ which however the lowest lignin degradation rate was observed at $\mathrm{pH} 13$ was $34.2 \%$ at the end of the incubation time. Santos et al., [8] studied the potentiality of Pleurotus spp to treat the effluent from bleached kraft pulp and the efficient treatment occurred in acid medium (pH 3.9 - 5.0) with the shaking of the effluent. Pratibha Singh et al., [7] studied the removal of colour in the paper mill effluent in a two-step bio-reactor which showed a reduction in colour $80 \%$ by Paceliomyces sp. whereas Microbrevis luteum showed removal in colour $59 \%$ by day 3 when 7 days anaerobically treated effluent was further treated by microorganisms. The specific objectives of the study are as follows:

- To find the degradation efficiency of different lignin degrading microorganisms and to identify the one with better degradation ability.

- Optimization of the better degrading microbe with HRT.

\section{MATERIALS AND METHODS}

\subsection{Wastewater Collection and Characterization}

The sample for the present study was collected from Hindustan Newsprint, located in Kottayam, Kerala and analyzed for various physicochemical characteristics as per the standard methods for the examination of water and wastewater (APHA 2005).

\subsection{Reactor Setup}

The treatment system consists of two batch reactors in series. The first reactor is maintained at anaerobic condition and the second at aerobic condition. The schematic diagram of reactor set up is shown in Chart 1.

\subsubsection{Anaerobic Bioreactor}

The anaerobic reactor was a rectangular shaped container having a capacity of $20 \mathrm{~L}$ with dimensions $14 \mathrm{~cm} \mathrm{x} 21 \mathrm{~cm} \mathrm{x}$ $70 \mathrm{~cm}$. Rubber tubes were provided to connect anaerobic system with aerobic.

\subsubsection{Aerobic Bioreactor}

The system consists of four containers having 1L capacity of dimension $15 \mathrm{~cm} \times 10 \mathrm{~cm} \times 12 \mathrm{~cm}$. It was filled with $10 \%$ gravel to provide support for immobilization of microorganisms. Aerators were provided for aeration.

\subsubsection{Microorganisms}

Two sets of fungal and bacterial strains were used for the treatment. Fungal species include Rhizopus stolonifer and Pluerotus species and bacterial species include Pseudomonas aeruginosa and Bacilus subtilis collected from Microbial Culture Collection Centre, Pune.



Chart-1: Schematic diagram of the experimental setup

\subsection{Method of Treatment}

Anaerobic container was filled with wastewater sample (18L) which was inoculated with $10 \%$ cow dung. The anaerobically treated effluent was then equally fed to the 4 aerobic containers containing the fungal (F1, F2) and bacterial species (B1, B2) after 1, 3, 5, 7 and 9 days. The effluent from the anaerobic and aerobic containers was analyzed for $\mathrm{pH}$, TS, BOD, COD, colour and lignin content after 1, 3, 5, 7and 9 days. The Effluent was supplemented with nutrients - sucrose $(0.2 \%)$ and urea $(0.1 \%)$.

The lignin of the effluent was estimated using the method of Pearl and Benson (1990) [6]. In this method, the sample was centrifuged at 10,000 rpm for 30 minutes to remove all the suspended matter. The $\mathrm{pH}$ of the sample was adjusted to 7.6 with $2 \mathrm{M} \mathrm{NaOH}$. The sample $(50 \mathrm{ml})$ was mixed with $1 \mathrm{ml}$ $\mathrm{CH}_{3} \mathrm{COOH} 10 \%$ and $1 \mathrm{ml} \mathrm{NaNO}{ }_{2} 10 \%$. After $15 \mathrm{~min} 2 \mathrm{ml}$ of $\mathrm{NH}_{4} \mathrm{OH}$ was added. The mixture was left for $5 \mathrm{~min}$ and absorbance was measured at $430 \mathrm{~nm}$. Blank was also prepared in the same procedure and absorbance was taken at $430 \mathrm{~nm}$ after $5 \mathrm{~min}$.

\section{RESULTS AND DISCUSSION}

\subsection{Characterization of Samples}

The effluent was collected and analyzed as per the standard methods. Table 1 shows the results of the analysis of the samples. It shows that the effluent is highly coloured and has very high $\operatorname{BOD}(14,900 \mathrm{mg} / \mathrm{L})$, COD $(16,000 \mathrm{mg} / \mathrm{L})$, TS $(5200 \mathrm{mg} / \mathrm{L})$ and lignin content $(5980 \mathrm{mg} / \mathrm{l})$.

The results obtained by the analysis of effluent from both the reactors clearly indicated that the reduction of pollution load by the aerobic reactor was more pronounced. Anaerobic treatment showed a reduction in colour 53\%, lignin $63 \%$, COD 43\%, BOD 59\% and TS 53\% in 7 days. The analysis of the effluent from aerobic reactor, which was previously anaerobically treated, shows that the white rot fungus Rhizopus stolonifer has maximum potential to remove colour and other parameters. 
Table 1: Analysis of paper mill effluent

\begin{tabular}{|c|c|c|c|}
\hline $\begin{array}{l}\text { Sl. } \\
\text { No. }\end{array}$ & Parameter & $\begin{array}{l}\text { Value } \\
\text { Obtained }\end{array}$ & $\begin{array}{l}\text { Tolerance limit } \\
\text { for Discharge } \\
\text { into inland } \\
\text { surface water } \\
\text { (CPCB 2012) }\end{array}$ \\
\hline \multicolumn{4}{|c|}{ Physical Parameters } \\
\hline 1 & $\mathrm{pH}$ & 7.43 & $5.5-9$ \\
\hline 2 & Temperature & $32^{\circ} \mathrm{C}$ & $40^{\circ} \mathrm{C}$ \\
\hline 3 & Colour & Dark Brown & Colourless \\
\hline 4 & Turbidity & $740 \mathrm{NTU}$ & $5 \mathrm{NTU}$ \\
\hline \multicolumn{4}{|c|}{ Chemical Parameters } \\
\hline 5 & Hardness & $\begin{array}{c}\text { Non } \\
\text { detectable }\end{array}$ & $600 \mathrm{mg} / \mathrm{L}$ \\
\hline 6 & Total Solids & $5200 \mathrm{mg} / \mathrm{L}$ & $600 \mathrm{mg} / \mathrm{L}$ \\
\hline 7 & BOD & $14,900 \mathrm{mg} / \mathrm{L}$ & $30 \mathrm{mg} / \mathrm{L}$ \\
\hline 8 & COD & $16,000 \mathrm{mg} / \mathrm{L}$ & $250 \mathrm{mg} / \mathrm{L}$ \\
\hline 9 & Lignin & $5980 \mathrm{mg} / \mathrm{L}$ & - \\
\hline 10 & Oil \& Grease & $\begin{array}{c}\text { Non- } \\
\text { detectable }\end{array}$ & $10 \mathrm{mg} / \mathrm{L}$ \\
\hline 11 & Sulphate & $1780 \mathrm{mg} / \mathrm{L}$ & $200 \mathrm{mg} / \mathrm{L}$ \\
\hline 12 & Phosphate & $100 \mathrm{mg} / \mathrm{L}$ & $5 \mathrm{mg} / \mathrm{L}$ \\
\hline
\end{tabular}

Chart. 2 shows the variation of $\mathrm{pH}$ with HRT for the effluents from both the reactors. Slight decrease in $\mathrm{pH}$ was observed during the treatment process (from 7.4 to 5.2). It may be due to conversion of complex organic compounds into simple organic acids.

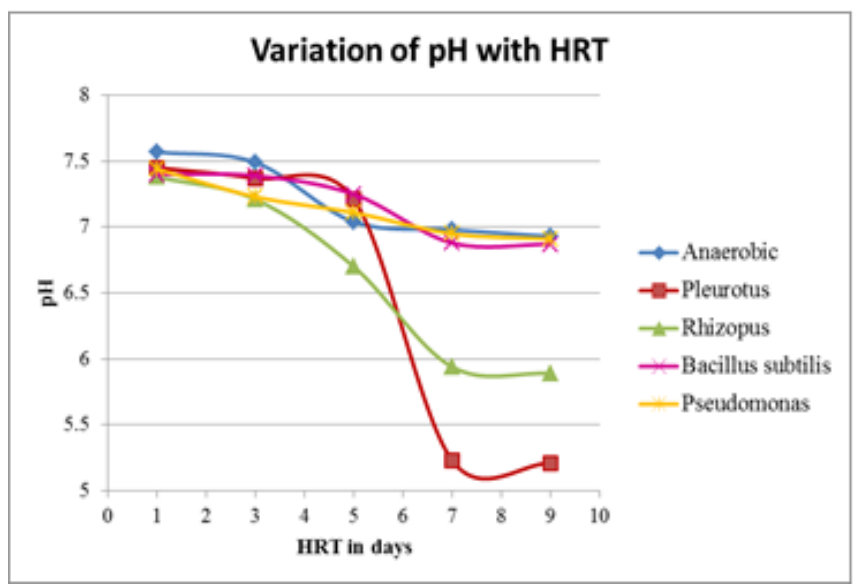

Chart 2. Effect of HRT on pH

The Rhizopus showed about $100 \%$ colour reduction in 7 days. Pleurotus, Bacillus subtilis and Pseudomonas showed $97 \%, 72 \%$ and $69 \%$ colour reduction respectively. Percentage colour reduction is shown in Fig. 3. The two fungal species showed good colour reduction than the bacterial species. This might be due to capability of white rot fungus to secrete enzymes that efficiently degrade colour causing compounds.

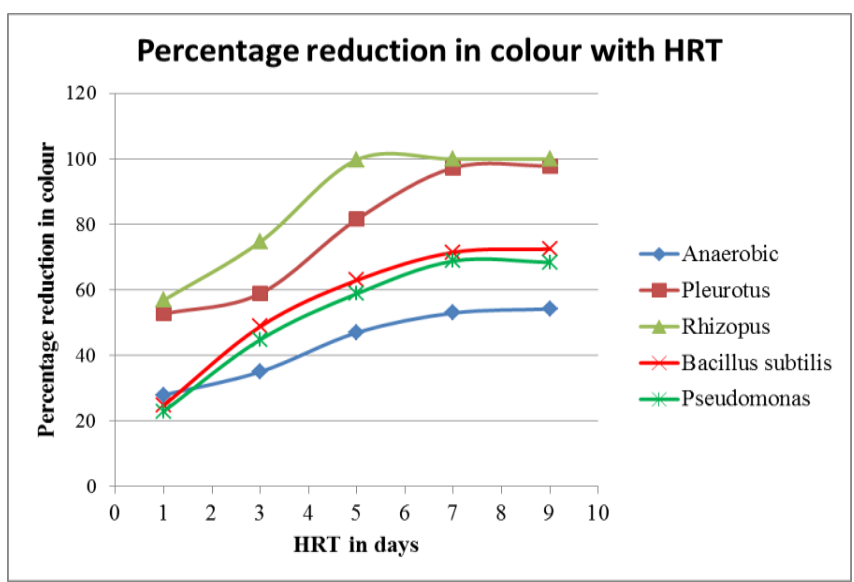

Chart 3. Percentage reduction in colour with HRT

Lignin content results in the dark brown colour due to formation of lignin compounds. Rhizopus shows good percentage removal of lignin (99\%) than the bacterial species. Anaerobic treatment gives $63 \%$ reduction in lignin content after 7 days. Percentage reduction in lignin content with HRT is shown in Chart. 4.

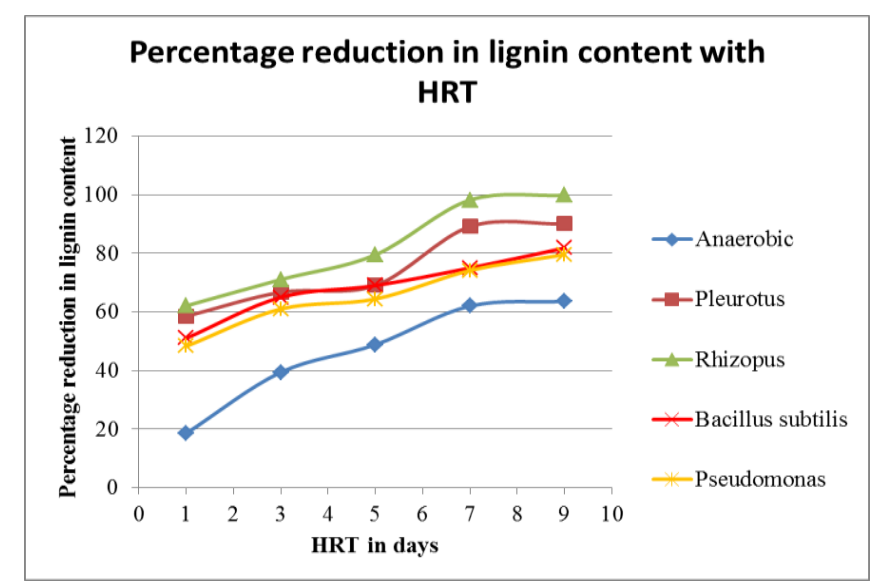

Chart 4. Percentage reduction in lignin content

COD of the effluent is reduced to $40 \%$ by anaerobic treatment process as shown in Chart. 5. It is further reduced to $94 \%$ by Rhizopus sp. The other species Pleurotus shows only $80 \%$ Bacillus $72 \%$ and Pseudomonas $62 \%$ removal efficiency. This is due to the mineralization of chlorolinin compounds by white rot fungus.

BOD is also reduced by $98 \%$ by both the fungal species whereas reduction is only about $80-87 \%$ for bacterial species. In anaerobic process BOD reduces about $59 \%$. This is considered as the result of mineralization of chlorinated compounds in the effluent by the enzymes. The percentage reduction in BOD is shown in Chart. 6. 


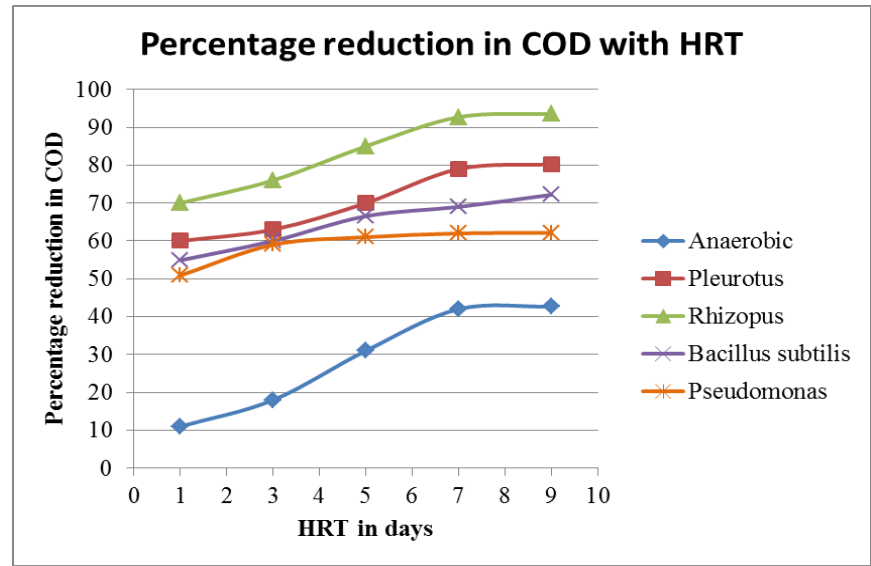

Chart 5. Percentage Reduction in COD with HRT



Chart. 6 Percentage reduction in BOD with HRT

Rhizopus also shows good reduction in total solid content. About $98 \%$ reduction is achieved by Rhizopus. Pleurotus, Bacillus and Pseudomonas show about $86-91 \%$ reduction. The percentage reduction is shown in Fig. 7. The data indicated that degradation of pollution parameters was comparatively fast in aerobic treatment than anaerobic treatment.

Thus combination of anaerobic and aerobic treatment was more efficient in removal of colour and chlorinated compounds, because anaerobic microorganisms are capable to remove highly chlorinated substances more efficiently than anaerobic microorganisms

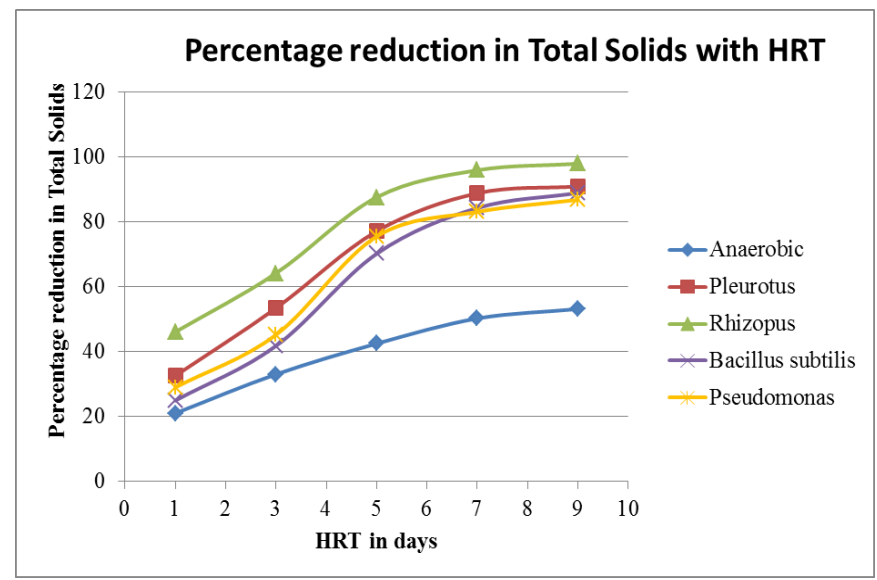

Chart. 7 Percentage Reduction In TS With HRT

\section{CONCLUSION}

Treatment of pulp and paper mill is very important as it contain high BOD and COD and also imparts dark brown colour which reduces photosynthetic activities and affects aquatic life. In the present study among the four microbial species used Rhizopus stolonifer was identified as the microbe having good degradation. It shows a reduction of colour - $100 \%$, lignin - $98.9 \%$, BOD - 97.58\%, COD $92.78 \%$ and TS- $98 \%$ at HRT of 7 days. Therefore degradation by white rot fungus is a promising technology in treatment of paper mill effluent.

\section{ACKNOWLEDGEMENT}

First and foremost I would like to express my whole hearted thanks to the invisible, the indomitable God for his blessings showered upon us in enabling to complete my work. I express my deep sense of gratitude to my guide Mr Vijayan. N, Associate Professor, Department of Civil Engineering, College of Engineering, Trivandrum, for his help, advice, support, constant encouragement and valuable guidance. I avail this opportunity to express my profound thanks to Dr. M. Satyakumar, Head of Department, Department of Civil Engineering, College of Engineering, Trivandrum, whose encouragement was a great source of inspiration. I express my sincere thanks to Prof. Sheeja A. K, P.G Professor, Prof. Shibu. K, Head of the Environmental Engg. Division, Dr. Jeenu G, Staff Advisor, and to the thesis coordinators, Department of Civil Engineering, College of Engineering, Trivandrum. My sincere thanks are extended to all teachers in the Department of Civil Engineering and to all my friends, and family whose inspiration has contributed to accomplish this work

\section{REFERENCES}

[1] APHA, Standard methods for the examination of water and waste water. American Public Health Association, Washington D.C. (2005)

[2] Gomathi, V., Ramanathan, B., Sivaramaiah, A., Ramanjaneya, V., Lula, R., Jayasimha, R, D., (2012). "Decolourization of paper mill effluent by immobilized cells of phanerochaete chrysosporium".International Journal of Plant, Animal and Environment Sciences, Vol. 2, pp141-146.

[3] Hassan, E., Abd-Elsalam., Amr, A., El-Hanafy., (2009). "Lignin biodegradation with Lignolytic bacterial strain and comparison of Bacillus subtilis and Bacillus sp. Isolated from Egyptian soil". Journal of Agric \& Environmental Science, Vol. 5, pp 39-44.

[4] Lokeshwari, N., Srinikethan, G., Joshi, S G., Shasikala Inamdar., Srikanth, B., Bashirahmed., Sushema, L., (2013). "Isolation of fungi for delignification of Pulp and paper mill effluent" International Journal of current Engineering and technology, Vol. 15, pp 3943.

[5] Prabibha Singh., Indu Shekhar Thakur., (2004). "Removal of colour and detoxification of pulp and paper mill effluent by microorganisms in two step bioreactor". Journal of scienific \& industrial Research, Vol. 63, pp 944-948. 
[6] Prathibha Singh., (2005) "Sequential anaerobic and aerobic treatment of pulp and paper mill effluent in pilot scale bioreactor". Journal of Environmental Biology, Vol. 28, pp 77-82.

[7] Prathibha Singh., Ashima Srivastava., (2014). "Enzymatic colour removal of pulp and paper mill effluent by different fungal strains". International journal of Pharma and Biosciences, Vol. 5, pp 773783.

[8] Santos, A, Z., Tavares, C, R, G., Gomes-da-Costa, S, M., (2002). "Treatment of the effluent from a kraft bleach plant with the white rot fungus Pleurotus ostreatoroseus sing”. Brazilian Journal of Chemical Engineering, Vol. 19, pp 371- 375.

[9] Shanthi, J., Krubakaran, C, T, B., Balagurunathan R., (2012). "Characterization and isolation of paper mill effluent degrading microorganisms". Journal of Chemical and isolation of paper mill effluent degrading microorganisms, Vol. 4 (10) pp 4436-4439.

[10] Shreeshivadasan, C., Siti Baizura, Mt., Md. Fadjil., Md. Din., Yuzir, A., and Othman, N., (2012). "Anaerobic Digestion of Paper Mill Wastewater". Iranica Journal of Energy \& Environment, Vol.3, pp 85-90. 